\author{
NANAEKE \\ Indonesian Journal of Early Childhood Education \\ Volume 4, Nomor 1, Juni 2021
}

\title{
CAPAIAN ASPEK PERKEMBANGAN SENI DAN STIMULASINYA PADA ANAK USIA 3- 4 TAHUN
}

\author{
Eka Damayanti \\ Universitas Islam Negeri Alauddin Makassar, \\ eka.damayanti@uin-alauddin.ac.id \\ Muhammad Rusydi Rasyid \\ Universitas Islam Negeri Alauddin Makassar, \\ muhammad.rusydi@uin-alauddin.ac.id \\ Andi Rezeky Amaliah \\ Universitas Islam Negeri Alauddin Makassar, \\ aandirezeky@gmail.com \\ Hijriah \\ Universitas Islam Negeri Alauddin Makassar, \\ hijriahsaleh08@gmail.com
}

\begin{abstract}
Abstrak
Perkembangan seni merupakan salah satu aspek yang sangat penting distimulasi sejak dini. Penelitian ini bertujuan untuk mengetahui gambaran perkembangan seni pada anak usia 3 - 4 tahun berdasarkan Standar Tingkat Pencapaian Perkembangan Anak dan menentukan stimulasi yang tepat untuk anak. Penelitian ini jenis studi kasus yang memiliki subjek 4 anak yang berusia 3 - 4 tahun yang dipilih secara purposive sampling. Instrumen pengumpulan data berupa pedoman observasi dan wawancara yang disusun oleh peneliti berdasarkan Standar Tingkat Pencapaian Perkembangan Anak. Analisis data menggunakan narasi deskriptif. Hasil penelitian menunjukkan bahwa keempat subjek telah memenuhi capaian perkembangan pada aspek seni anak berdasarkan standar usia subjek khususnya dalam hal mampu membedakan antara bunyi dan suara; tertarik dengan kegiatan musik, gerakan orang, hewan maupun tumbuhan; dan tertarik dengan kegiatan atau karya seni. Keberhasilan capaian perkembangan pada subjek tidak terlepas dari stimulasi yang dilakukan oleh orang tua atau pendidik oleh karena itu hasil penelitian ini mengimplikasikan kepada orangtua atau pendidik agar selalu memberikan stimulasi yang tepat agar perkembangan seni anak dapat mencapai standar normal.
\end{abstract}

Kata Kunci: Aspek Perkembangan Seni; Capaian Perkembangan Seni; Stimulasi

\section{Abstract}

The development of art is one aspect that is very important to stimulate from an early age. This study aims to describe the art development in children aged 
3 to 4 years based on the Child Development Achievement Level Standards also determine the appropriate stimulations for children. This case studio used a qualitative approach. The subjects of the study were four children aged 3-4 years, selected by purposive sampling. The instruments used were observation forms and interview guidelines prepared by the researcher based on the Child Development Achievement Level Standards. The data collected was analyzed with a descriptive narrative. The results showed that the four subjects had met the developmental achievements in children's art aspect based on the subject's age standard. Especially to different noises and sounds; interested in musical activities, people movement, animals and plants; and are interested in arts activities. It is clear that the stimulus provided by parents or educators intimately connected to developmental achievement in the subject. Therefore, the results of this study imply the parents or educators to provide proper stimulation frequently to meet the children's artistic development with the expected standards.

Keywords: Aspects of Art Development; Achievement of Art Development; Stimulation

\section{PENDAHULUAN}

Periode perkembangan pada anak usia dini merupakan periode yang sangat penting dalam rentang pertumbuhan dan perkembangan manusia. Usia anak usia dini popular disebut dengan golden age yang berarti masa keemasan atau masa kejayaan. Orang tua dan guru sebagai lingkungan terdekat dari anak menjadi penentu dalam memberikan stimulasi yang tepat pada anak agar mampu menjalani periode golden age dengan optimal. Stimulasi yang diberikan pada anak dapat dilakukan di rumah maupun di pendidikan formal atau Pendidikan Anak Usia Dini (PAUD). Pendidikan Anak Usia Dini berdasarkan Peraturan Menteri Pendidikan dan Kebudayaan Nomor 137 Tahun 2014 adalah upaya pembinaan yang ditujukan kepada anak sejak lahir sampai usia 6 (enam) tahun yang dilakukan melalui pemberian rancangan pendidikan untuk membantu pertumbuhan dan perkembangan jasmani dan rohani agar anak memiliki kesiapan dalam memasuki pendidikan lebih lanjut. Pendidikan di PAUD menurut Sujiono (2009) menitikberatkan peletakkan dasar ke arah pertumbuhan dan perkembangan fisik (koordinasi motorik halus dan kasar), kecerdasan (daya pikir, daya cipta, kecerdasan emosi, kecerdasan spiritual), sosial emosional (sikap dan perilaku serta beragama, bahasa dan komunikasi).

Pendidikan yang berlangsung di PAUD seyogianya berlangsung dalam bentuk pembelajaran dan pelatihan kebiasaan yang didesain dalam bentuk permainan, dan suasana riang, dan seperti di dalam keluarga. Suasana pendidikan yang baik dan tepat adalah dalam suasana kekeluargaan dengan prinsip asih (mengasihi) asah (memahirkan) - asuh (membimbing). Pemberian stimulus yang baik dan teratur kepada anak dapat menjadi dorongan pada anak agar dapat berkembang

2 NANAEKE - Indonesian Journal of Early Childhood Education, Vol. 4, No. 1, Juni 2021 
sesuai dengan standar perkembangan yang seharusnya dipenuhi sesuai usianya (Riyanto \& Martin, 2004).

Stimulasi perkembangan pada anak usia dini dapat dilakukan dalam lingkup keluarga dan dalam lingkup pendidikan formal yakni lembaga satuan Pendidikan Anak Usia Dini (PAUD). Menurut Rifda (2017) kehadiran PAUD dapat memberikan pembinaan dan memberikan rangsangan yaitu pendidikan guna mengembangkan pertumbuhan dan perkembangan rohani dan jasmani anak sehingga mempunyai kesiapan untuk memasuki tahapan pendidikan selanjutnya. Lebih lanjut penjelasan Khadijah (2016) stimulasi pada anak usia dini sangat penting dilakukan karena perkembangan anak usia dini tidak bisa diulang lagi. Stimulasi yang diberikan pada anak usia dini dimasa sekarang akan berdampak pada kualitas anak dimasa depan.

Pemberian stimulasi akan menjadi efektif jika orang tua atau pengasuh memberikan dan memperhatikan kebutuhan anak sesuai dengan tahapan perkembangan anak. Salah satu perkembangan yang sangat penting untuk dipantau pada anak dalam periode ini adalah perkembangan seni anak. Menurut Pakerti (2010) pendidikan seni pada anak adalah membantu anak untuk mengungkapkan sesuatu yang mereka ketahui dan yang dirasakan oleh mereka sehingga dapat diungkapkan dalam bentuk seni. Karya seni yang dimiliki anak merupakan ungkapan keindahan dari suatu peristiwa yang mereka rasakan. Pendidikan seni di Indonesia terdapat beberapa macam yakni seni rupa, seni tari, dan seni musik semua dikembangkan sesuai dengan tahap perkembangan dan aspek-aspek perkembangan anak. Mendidik anak melalui seni, tidak hanya untuk anak berbakat saja, tetapi seni juga dapat mengembangkan potensi diri dan menumbuhkan kreatifitas anak.

Namun fakta yang terjadi, tidak semua orangtua atau pendidik mampu memberikan stimulasi yang tepat pada anak sehingga perkembangan anak mengalami hambatan. Salah satu faktor yang menyebabkan karena orang tua atau pendidik kurang memahami langkah apa yang seharusnya mereka lakukan. Selain itu, tidak adanya pengetahuan yang dimiliki orang tua sampai titik mana perkembangan seharusnya yang harus dicapai anak khususnya pada aspek perkembangan seni.

Hal tersebut sejalan dengan penelitian yang dilakukan oleh (Sari, 2020) yang mengungkapkan bahwa, salah satu faktor penyebab anak mengalami hambatan perkembangan yaitu orang tua atau guru kurang memahami dalam pemberian stimulasi kepada anak dikarenakan kurangnya pemahaman orang tua dalam tahapan aspek perkembangan anak terutama pada aspek perkembangan seni. Pendapat yang sama juga diungkapkan oleh Miskawati (2017) yaitu salah satu faktor yang menghambat perkembangan anak dalam aspek seni yaitu kurangnya pemahaman orang tua dalam pemberian stimulasi yang tepat.

Oleh karena itu sangat penting mengetahui capaian perkembangan anak 
sesuai dengan usia tahapan perkembangan agar dapat dideteksi secara dini aspek mana saja yang kurang. Selain itu, pengetahuan terkait capaian perkembangan anak sangat berguna dalam menetapkan stimulasi yang tepat pada anak sesuai dengan tugas perkembangan anak. Dalam artikel ini bertujuan untuk mengetahui gambaran perkembangan seni pada anak usia 3 - 4 tahun berdasarkan Standar Tingkat Pencapaian Perkembangan Anak (STTPA) dan menentukan stimulasi yang tepat untuk anak.

\section{METODE PENELITIAN}

Penelitian ini menggunakan pendekatan kualitatif jenis studi kasus. Subjek penelitian sebanyak empat anak (inisial AS, MF, AA dan SA) yang dipilih secara purposive sampling berdasarkan kriteria: (1) Anak usia dini berusia 3 - 4 tahun; (2) Mudah dijangkau oleh peneliti selama pandemi covid-19; (3) Orangtua anak menyatakan kesediaan membantu selama proses wawancara dan observasi pada anak. Lokasi penelitian dilakukan di Kabupaten Polewali Mandar, Provinsi Sulawesi Barat.

Data dikumpulkan menggunakan teknik observasi dan wawancara. Peneliti sebagai intrumen kunci menggunakan bantuan pedoman observasi dan wawancara yang disusun berdasarkan indikator tingkat pencapaian perkembangan berdasarkan tingkat pencapaian perkembangan anak dalam Peraturan Menteri Pendidikan dan Kebudayaan Republik Indonesia Nomor 137 Tahun 2014 Tentang Standar Nasional Pendidikan Anak Usia Dini, khususnya pada aspek perkembangan seni pada anak usia 3 - 4 tahun. Pertama, mampu membedakan antara bunyi dan suara, ditandai dengan kemampuan yakni (1) Mengenali berbagai macam suara dari Kendaraan; (2) Meminta untuk diperdengarkan lagu favorit secara berulang. Kedua, Tertarik dengan kegiatan musik, gerakan orang, hewan maupun tumbuhan, ditandai dengan kemampuan yakni (1) Mendengarkan atau menyanyikan lagu; (2) Menggerakkan tubuh sesuai dengan irama; (3) Bertepuk tangan sesuai dengan irama musik; (4) Meniru aktivitas orang baik secara langsung maupun melalui media. (misal, cara minum/cara bicara/perilaku seperti ibu); (5) Bertepuk tangan dengan pola yang berirama (misalnya, bertepuk tangan sambil mengikuti irama nyanyian). Dan Ketiga, Tertarik dengan kegiatan atau karya seni, ditandai dengan kemampuan yakni (1) Menggambar dengan menggunakan beragam media (cat air, spidol, alat menggambar) dan cara (seperti finger painting, cat air, dll); (2) Membentuk sesuatu dengan plastisin; dan (3) Mengamati dan membedakan benda disekitarnya yang diluar rumah.

Data yang dikumpulkan selanjutnya dianalisis dengan cara dinarasikan secara deskriptif dengan menggambarkan secara lengkap dan menyeluruh hasil observasi dan wawancara berdasarkan indikator tingkat pencapaian perkembangan seni pada anak. untuk menjaga keabsahan data supaya hasil penelitian ini memenuhi standar derajat kepercayaan, maka peneliti lakukan (1)

4 NANAEKE - Indonesian Journal of Early Childhood Education, Vol. 4, No. 1, Juni 2021 
Memperpanjang pengamatan, dilakukan dengan penelitian selama tiga bulan; (2) Ketekunan pengamatan, dilakukan dengan memperhatikan perbedaan secara detail tiap capaian perkembangan tidak muncul pada saat observasi dan wawancara dilakukan; (3) Triangulasi, dilakukan dengan membandingkan data hasil observasi dengan data hasil wawancara, itu juga membandingkan temuan pada anak dengan hasil wawancara dari orang tua anak.

\section{HASIL DAN PEMBAHASAN}

Hasil penelitian menunjukkan bahwa ke empat subjek AS, MF, AA dan SA. telah memenuhi Standar Tingkat Pencapaian Perkembangan Seni pada anak usia 3 - 4 tahun. Hasilnya secara detail dapat digambarkan sebagai berikut:

\section{Membedakan antara bunyi dan suara}

\section{Mengenali berbagai macam suara dari kendaraan}

Berdasarkan hasil observasi Subjek MF mampu mengenali berbagai macam suara hewan ataupun kendaraan. Seperti pada hewan ketika diberikan contoh suara hewan dengan mudah dan cepat dapat ia kenali. Jika diberikan perintah untuk mengikuti suara hewan yang disebutkan maka MF akan mencoba untuk meniru bersuara seperti apa yang diinstruksikan. Sama halnya dengan kendaraan sudah mampu membedakan suara mobil, motor dan suara pesawat ketika ada yang sementara melintas dilangit. MF sudah mampu mengenali dan membedakan suara kendaraan anggota keluarganya seperti bunyi motor bapaknya, maupun suara motor yang ada disekelilingnya juga hampir sudah bisa ia kenali. Begitu pula dengan subjek AS sudah mampu mengenali berbagai macam suara dari kendaraan, seperti motor, mobil baik itu mobil kecil maupun mobil truk besar. Terkadang ketika peneliti berada diteras berdua dengan AS, dia akan selalu berkata "itu mobil besar, itu motor". Bahkan selepas ia mendengarkan bunyi suara motor ayah atau ibunya, anak itu berlari keluar untuk menghampirinya. Sama halnya dengan AA yang bahkan mampu mengenali suara traktor dan mesin pemotong pohon serta suara-suara binatang. Hal yang sama juga dialami oleh SA yang sudah mampu untuk mengenali suara motor bapaknya contohnya ketika bapaknya baru pulang jualan dan dia dari dalam rumah bilang kepada mamanya "itu bapak pulang mak" dan SA keluar menghampiri bapaknya.

\section{Meminta untuk diperdengarkan lagu favorit secara berulang}

Subjek MF sangat menyukai dalam hal bernyanyi dan sering meminta untuk diperdengarkan atau dinyanyikan lagu favoritnya untuk kemudian ia hapalkan sendiri. Kesehariannya MF biasanya juga sangat suka menyanyikan lagu yang ingin dia nyanyikan dari beberapa lagu yag dihapalnya. Contohnya seperti ketika dia mendengar orang disampingnya bernyanyi, dia juga akan mengikuti menyanyikan lagu tersebut. Kebanyakan lagu yang ia hapal dia dapatkan dari menonton tv, mendengarkan musik bahkan ia sering di downloadkan lagu anak-anak atau film 
anak-anak. Mulai dari film kartun, lagu anak, lagu dewasa baik pop maupun lagu barat dan lagu wajib. MF sangat menyukai lagu barat termasuk lagu anak-anak yang berbahasa Inggris, namun dia hanya menghapal apa yang ia dengarkan saja. Jadi, ketika menyanyikan lagu tersebut ia belum jelas artikulasi bahasa inggrisnya. Orangtuanya juga maupun keluarga dirumah sering menyuruhnya untuk bernyanyi lagu wajib nasional seperti Indonesia Raya dan beberapa lagu wajib nasional lainnya. Begitu pula dengan AS, AA dan SA, dia meminta kepada orangtua mereka diputarkan lagu yang mereka sukai saat mendengarkan lagu. Mereka kadang menyanyikan lagu tersebut. Ketika mereka juga menonton televisi baik itu kartun atau orang yang lagi sholawatan mereka akan mengikuti menyanyi jika dia hafal lagu tersebut.

Pada unsur membedakan antara bunyi dan suara, keempat subjek telah mampu mencapainya meskipun memang lebih dominan subjek MF. Stimulasi yang biasa dilakukan orang tua subjek: (1) Melatih sensitivitas pendengaran anak dengan banyak bertanya suara apa ini, suara apa itu; (2) Rajin memutarkan lagulagu yang disukai anak; dan (3) memutarkan lagu favorit anak dengan berulangulang. Hasil penelitian tersebut sejalan dengan pendapat Hirmaningsih (Tiurma, 2012) yang menjelaskan bahwa dalam kegiatan bernyanyi, terdapat dua bentuk yang dapat digunakan oleh anak. Pertama yaitu anak mendengarkan lagu/musik yang diputarkan tetapi anak tidak ikut bernyanyi, bentuk ini disebut dengan bernyanyi pasif. Sedangkan yang kedua yaitu anak bernyanyi baik secara langsung, mengikuti lagu yang diputarkan, kelompok ataupun dengan sendirinya.

Kemampuan anak dalam membedakan antara bunyi dan suara dapat disimpulkan bahwa keempat subjek telah mampu mencapainya. Stimulasi yang diberikan orang tua dalam mengembangkan aspek perkembangan seni anak pada unsur membedakan antara bunyi dan suara pun sudah tepat. Hal tersebut sesuai dengan pendapat yang dikemukakan oleh Astuti (2011) bahwa perkembangan dan kemampuan anak dalam unsur membedakan suara dan bunyi akan tercapai dengan baik apabila stimulasi yang diberikan tepat, seperti anak sering dilatih sensivitas pendengarannya, diputarkan lagu yang disenangi. Pendapat yang sama juga dijelaskan oleh Wulandari dkk (2020) bahwa pemberian stimulasi yang beragam dan sesuai pada tingkat perkembangan anak, dapat meningkatkan aspek perkembangannya.

\section{Tertarik dengan kegiatan musik, gerakan orang, hewan maupun tumbuhan Mendengarkan atau menyanyikan lagu}

Subjek MF sudah mampu mendengarkan atau menyanyikan lagu yang sangat ia sukai. MF mengikuti orang dewasa disekitarnya yang bernyanyi. MF terbiasa menyanyikan lagu dengan riang baik ia dalam keadaan belajar atau sementara bermain. MF juga suka mengaji, menghafal surah-surah pendek, dan doa-doa keseharian. Begitu pula dengan subjek AS yang sangat menyukai mendengarkan

6 NANAEKE - Indonesian Journal of Early Childhood Education, Vol. 4, No. 1, Juni 2021 
lagu sholawatan yang sering dinyalakan di handphone orangtuanya. Kegiatan bernyanyi sangat digemari AS, terkadang tanpa disuruh AS akan bernyanyi dengan sesuka hatinya. Terlihat juga, ketika mendengar lagu atau orang yang bernyanyi dengan spontan AS pun ikut bernyanyi. Sama halnya dengan subjek AA telah mampu mendengarkan dan menyanyikan lagu yang biasa diputarkan bahkan AA juga mengulang-ulangi lagu tersebut sambil mengikuti liriknya. Seperti ketika peneliti memperlihatkan video anak-anak yang bernyanyi, dengan spontan AA pun ikut bernyanyi mengikuti tarian dan lagu yang ada pada video tersebut. Dari hasil pengamatan juga terlihat saat responden melihat cicak, dengan perasaan gembira responden langung menyanyikan lagu cicak-cicak di dinding dengan nada yang benar. Sama dengan ketiga subjek lainnya, SA pun juga sudah mampu untuk menyanyikan lagu anak. Terlihat ketika SA diminta oleh ibunya untuk bernyanyi lagu "balonku ada lima" dan "bintang kecil", SA sangat berantusias menyanyikan lagu tersebut sambil bergoyang, meskipun masih ada beberapa kata yang tidak terlalu jelas diucapkan seperti kata rupa-rupa SA menyebutnya dengan kata lupa-lupa warnanya.

\section{Menggerakkan tubuh sesuai dengan irama}

Dari hasil observasi, subjek MF sudah mampu menggerakkan tubuhnya untuk bergoyang sesuai dengan irama lagu. Hal ini terlihat dari hasil pengamatan, subjek MF ketika diputarkan lagu/musik ia akan bergoyang mengikuti ketukan-ketukan irama dari lagu yang di putarkan. Sama halnya dengan Subjek AS ia juga sudah mampu menggerakkan tubuhnya mengikuti irama dengan keinginannya sendiri. Subjek AS sangat sering bergoyang ketika mendengarkan lagu baik itu lagu kesukaannya maupun lagu yang didengarkan langsung dari TV. Begitu pula dengan subjek AA sudah mampu mengerakkan tubuhnya (bergoyang) ketika diputarkan musik dan diminta untuk bergoyang. Dari hasil pengamatan, ketika ibu AA memutar musik tiktok diapun dengan asyik mengikut musiknya dan bergoyang seperti gerakan tiktok yang AA sering lihat di vidio. Terlihat ketika diputarkan musik, dengan spontan AA mengepal kedua tangannya lalu melangkah maju mundur. Lain halnya dengan SA, dari hasil pengamatan SA akan menggerakan badannya ketika diputarkan lagu dan diminta bergoyang, misalnya ketika SA diminta untuk bergoyang dia pun akan bergoyang dengan memutar-mutarkan tubuhnya dan mengangkat kedua tangannya sambil tersenyum dan bermain mata.

Tak lupa orang tua dari ke empat subjek mendukung kegiatan anak dengan memberikan reward apabila telah melakukan kegiatan. Hal ini sejalan dengan pendapat Farida dkk (2020) dalam penelitiannya mengatakan bahwa untuk mendukung minat anak dalam kegiatan seni, orangtua atau guru dapat memberikan stimulasi berupa fasilitas yang dapat mengembangkan perkembangan seni anak dan memberikan reward atau hadiah apabila anak berhasil melakukan hal positif. 


\section{Bertepuk tangan sesuai dengan irama musik}

Dari hasil penelitian, keempat subjek telah mampu bertepuk tangan sesuai dengan irama musik. Hal ini terlihat ketika MF diputarkan lagu favoritnya ia langsung bernyanyi sambil bertepuk tangan mengikuti irama musik. Pada tahap ini, subjek AS ketika diminta untuk bernyanyi ia akan bertepuk tangan beberapa kali sampai lagu yang dinyanyikannya selesai ia pun juga akan berhenti bertepuk tangan. Hal lain yang ditemukan, ketika subjek AS mendengar orang disekitarnya bernyanyi maka ia akan mengikuti lagu tersebut dengan gerakan tepuk tangan yang mengikuti ketukan lagunya. Sama halnya dengan subjek AA, ketika diminta untuk bertepuk tangan dengan memutarkan musik (lagu tepuk-tepuk tangan) AA dengan spontan bertepuk-tepuk tangan sambil mengikuti irama dan lirik lagu yang diperintahkan. Sedangkan subjek SA, Pada tahap ini juga telah mampu untuk melakukannya, dimana ketika diminta untuk bertepuk tangan sambil menyanyikan lagu tepuk-tepuk tangan SA akan bernyanyi sembari bertepuk tangan beberapa kali tepukan meskipun terkadang masih ada tepukan yang belum sesuai dengan irama musik tetapi SA mampu melakukannya.

\section{Meniru aktivitas orang baik secara langsung maupun melalui media. (misal, cara minum/cara bicara/perilaku seperti ibu)}

Pada tahap ini subjek MF sudah mampu meniru aktivitas kesehariannya dirumah baik itu secara langsung maupun melalui media, terkadang ia sering meniru atau mengikuti tingkah laku apa yang ia lihat seperti mengikuti tingkah laku cara duduk kakeknya, orangtua maupun orang yang disekitarnya. Begitu pula dengan Subjek AS juga sudah mampu meniru aktivitas orang baik secara langsung maupun melalui media. Kesehariannya ia sering meniru bahkan mengikuti apa yang sering dilakukan orang disekitarnya. AS sudah bisa mengamalkan sopan santun yang baik seperti duduk dengan baik, mengucapkan salam ketika ingin masuk dirumah, ramah dengan temannya bahkan jika ada orang disekitarnya, maka ia akan berkata "Tabe Puang" atau permisi hal tersebut merupakan hasil dari peniruan kebiasaan orang-orang disekitarnya. Sama halnya dengan AS, Subjek AA dan SA sudah mampu menirukan tingkah laku seperti ketika kita berbicara AA juga mengulangi kata-kata yang diucapkan bahkan meniru gaya-gaya berbicara orang yang dia lihat. SA bisa menirukan aktivitas orang yang dilihat, hal tersebut terlihat pada saat ayah SA sedang membersihkan kandang sapi dan mengelus-ngelus kepala sapi, ia pun menghampiri ayahnya. Tanpa rasa takut SA langsung mengelusgelus sapi dan memberikan rumput yang ada didekatnya untuk dimakan oleh sapi tersebut seperti yang biasa dilakukan ayahnya.

\section{Bertepuk tangan dengan pola yang berirama (misalnya bertepuk tangan sambil mengikuti irama nyanyian)}

Pada tahapan ini, Subjek MF sudah mampu bertepuk tangan dengan pola yang berirama, seperti bertepuk tangan sambil mengikuti irama nyanyian. Ketika

8 NANAEKE - Indonesian Journal of Early Childhood Education, Vol. 4, No. 1, Juni 2021 
diminta untuk menyanyikan lagu yang sangat ia senangi sambil bertepuk tangan, MF sudah mampu menyelaraskan tepuk tangannya ketika menyanyikan lagu kesukaannya. Pada tahap ini, Subjek AS jika disuruh untuk bernyanyi bersamaan dengan melakukan tepuk tangan ia sudah mampu menyelaraskan tepuk tangannya berdasarkan dengan lagu yang ia nyanyikan. Lain halnya dengan subjek AA dan SA, pada tahap ini AA dan SA hanya bertepuk tangan tanpa mengikuti irama sehingga mereka hanya mampu melakukan tepuk tangan saja.

Hasil penelitian di atas sejalan dengan pendapat Sandor (1975) bahwa gerak dan lagu dalam bentuk bernyanyi dan latihan gerak tubuh sangat berhubungan erat karena irama lagu dapat mempengaruhi dan mengendalikan pusat syaraf. Dengan demikian pembelajaran melalui gerak dan lagu yang dilakukan sambil bermain akan membantu anak untuk lebih mengembangkan kecerdasannya tidak hanya pada aspek pengembangan seni, bahasa dan fisiknya saja tetapi juga pada pengembangan emosional dan kognitif anak.

Pada unsur tertarik dengan kegiatan musik, gerakan orang, hewan maupun tumbuhan, keempat subjek telah mampu mencapainya meskipun memang lebih dominan subjek SA belum terlalu jelas dalam pengucapan kata-katanya. Stimulasi yang biasa dilakukan orang tua subjek: (1) Mendukung setiap lagu yang disukai anak; (2) Memberikan apresiasi tiap kesukaan anak; (3) Memfasilitasi anak untuk bernyanyi ataupun bergerak; (4) Memberikan selalu pengajaran kepada anak agar dapat bertingkah laku yang baik; dan (5) Mendukung apa yang telah dilakukan oleh anak.

Kemampuan anak dalam ketertarikan dengan kegiatan musik, gerakan orang, hewan maupun tumbuhan dapat disimpulkan, dengan pemberian stimulasi perkembangan anak akan mengalami peningkatan. Hal tersebut sesuai dengan teori atau pendapat yang dikemukakan oleh Marlina \& Mayar (2020) yang mengatakan bahwa apabila anak selalu diberikan stimulasi, lambat laun perkembangan anak dapat dilatih dan dikembangkan dengan melalui kegiatankegiatan yang menarik.

\section{Tertarik dengan kegiatan atau karya seni}

Menggambar dengan menggunakan beragam media (cat air, spidol, alat menggambar) dan cara (seperti finger painting, cat air, dII)

Dari hasil observasi, subjek MF sudah mampu menggambar ataupun menulis dengan menggunakan beragam media, seperti menggambar sebuah mobil, bangun datar serta mampu menggambar pelangi dan mampu mewarnainya sendiri dengan krayon. Terlihat ketika MF diminta untuk menggambar, MF akan menggunakan alat menggambar seperti seperti krayon, spidol dan pensil warna. Sama halnya dengan AS, Subjek AS sudah mampu menggambar menggunakan berbagai macam media seperti cat air, spidol dan krayon. AS paling senang ketika orangtuanya membelikan sebuah buku serta alat menggambar, ia akan menggambar apa yang ia lihat dibuku 
tersebut. Terlihat ketika ayah AS membelikan buku mewarnai, AS langsung berinisiatif untuk mewarnai gambar tersebut dengan pensil warna miliknya. Sama halnya dengan subjek AA dan SR, ketika diminta untuk memilih spidol atau pensil AA DAN SR lebih memilih spidol. Pada saat menggambar AA mencoret-coret buku dan tidak jarang kukunya juga diwarnai, dan ketika AA diminta untuk menggambar dia menggambar gari-garis panjang (bengkok) sambil mengatakan bahwa yang ia gambar adalah ular besar.

\section{Membentuk sesuatu dengan plastisin}

Subjek MF sudah mampu membentuk sesuatu dari adonan kue, terlihat MF membentuk bola-bola, lalu disatukan dijadikan seperti manusia salju. MF juga sering mencetak adonan kue tersebut pada cetakan mobil-mobilannya, dan memasukkan ke dalam lego agar terbentuk. Sama halnya dengan AS, AA, dan SA, dari hasil pengamatan AS, AA, dan SA membentuk mainan plastisin menjadi bulan, mie, dan bola-bola kecil.

\section{Mengamati dan membedakan benda disekitarnya yang diluar rumah}

Pada tahapan ini MF, AS, AA, dan SA sudah mampu mengamati dan membedakan benda disekitarnya baik yang didalam rumah ataupun yang ada diluar sekitaran rumahnya. Terlihat dari hasil observasi, subjek sudah bisa membedakan benda yang digunakan untuk makan, minum dan lain-lain. Selain itu keempat subyek sudah mampu membedakan antara suara motor dan mobil.

Kemampuan anak dalam ketertarikan dengan kegiatan atau karya seni dapat disimpulkan bahwa keempat subjek perkembangannya telah terpenuhi dengan baik dapat dilihat dari kegiatan yang dilakukan anak. Pemberian dukungan berupa kegiatan atau sesuatu yang disenangi anak dapat dijadikan stimulasi yang tepat. Hal tersebut sesuai dengan teori atau pendapat yang dikemukakan oleh Supriyenti (2013) tentang peningkatan kreatifitas anak melalui bahan alam, supriyenti mengatakan bahwa dukungan yang diberikan kepada anak dapat membantu peningkatan perkembangan anak apabila stimulasi yang diberikan menyenangkan.

Pada unsur tertarik dengan kegiatan atau karya seni. Keempat subjek telah mampu mencapainya meskipun subjek SR belum secara optimal memanfaatkan media yang digunakan untuk menggambar. Stimulasi yang biasa dilakukan orang tua subjek: (1) Memfasilitasi anak dengan memberikan alat yang digunakan untuk menggambar; (2) Memberikan apa yang diinginkan anak selama hal itu baik untuk mengembangkan imajinasinya; dan (3) Memotivasi anak agar dapat menimbulkan rasa ingin tahu dengan apa yang ada disekitarnya.

Pendapat di atas di dukung dengan hasil penelitian yang dilakukan oleh Damayanti dkk (2020) yaitu perkembangan seni pada anak usia dini dapat berkembang melalui pemberian stimulasi. Stimulasi yang dapat diberikan antara lain: (1) mendukung minat anak dengan memberikan media yang disenangi; (2) memberikan apresiasi berupa pujian yang dapat memotivasi anak; (3) memberikan 
fasilitas berupa alat permainan yang dapat mengembangkan aspek seni anak.

Hal di atas sejalan dengan pendapat Munandar (2002) mengatakan bahwa kreativitas seni merupakan pengalaman dalam mengekspresikan identitas individu dalam bentuk antara hubungan diri sendiri, alam dan orang lain. Sedangkan menurut Fadelis E. Waruwu (Widiasaran, 1999), kreativitas merupakan kemampuan seseorang untuk melahirkan sesuatu yang baru berupa gagasan maupun karya nyata, baik dalam karya baru maupun hal-hal yang sudah ada.

Pada hasil penelitian yang dilakukan, peneliti telah menggambarkan bahwa keempat anak (AS, MF, AA dan SA) telah memenuhi capaian perkembangan pada aspek Seni anak berdasarkan standar usia subjek khususnya dalam hal mampu membedakan antara bunyi dan suara (1. Mengenali berbagai macam suara dari Kendaraan; 2. Meminta untuk diperdengarkan lagu favorit secara berulang), Tertarik dengan kegiatan musik, gerakan orang, hewan maupun tumbuhan (1. Mendengarkan atau menyanyikan lagu; 2. Menggerakkan tubuh sesuai dengan irama; 3. Bertepuk tangan sesuai dengan irama music; 4. Meniru aktivitas orang baik secara langsung maupun melalui media; 5. Bertepuk tangan dengan pola yang berirama (misalnya bertepuk tangan sambil mengikuti irama nyanyian), Dan Tertarik dengan kegiatan atau karya seni (1. Menggambar dengan menggunakan beragam media (cat air, spidol, alat menggambar) dan cara (seperti finger painting, cat air, dlI); 2. Membentuk sesuatu dengan plastisin, dan 3. Mengamati dan membedakan benda disekitarnya yang diluar rumah).

Berdasarkan hasil wawancara yang dilakukan kepada orang tua anak, ditemukan bahwa mereka mendidik anak mereka dengan berbagai stumulasi. Adapun berbagai upaya yang telah dilakukan oleh orang tua dalam pemberian stimulasi yakni: 1) Membiasakan diri anak untuk bisa belajar bunyi-bunyian, 2) Selalu memberikan perhatian khusus pada hal yang membuat anak tertarik, 3) memberikan dukungan positif terhadap apapun karya seni anak, 4) Memutarkan lagu-lagu saat anak sedang bermain, 5), Memberikan kebebasan kepada anak untuk bergerak mengikuti melodi lagu dan 6) Memberinya pujian atau hadiah ketika anak sudah mampu melakukan apa yang diajarkan, dan 7) Membiasakan diri anak lebih baik bermain dibanding harus selalu memegang handphone.

Perkembangan seni pada anak usia dini akan sangat mudah distimulasi jika orangtua dan lingkungan mendukung serta memberikan stimulasi secara yang baik dan menyenangkan kepada anak. Ini membuktikan pada hasil penelitian yang dilakukan peneliti dengan mengambil sampel anak yang berusia 3-4 tahun (AS, MF, AA dan SA) bahwa peran orangtua dan lingkungan sangat mempengaruhi perkembangan anak terlebih untuk perkembangan seni anak. Sehingga, aspek perkembangan seni dapat berkembang sesuai dengan tahapan usia dan standar pencapaian pada perkembangan anak usia dini apabila terstimulasi dengan baik.

Setiap perkembangan seni yang diperoleh oleh anak tentunya berasal dari kecerdasan yang dimiliki oleh anak itu sejak dari lahir. Kecerdasan yang dibawa 
oleh anak tersebut selalu ia kembangkan sebagaimana kemauan yang diinginkan anak agar dapat tingkatkan kecerdasannya tersebut. Kecerdasan yang diperoleh anak tentunya tidak pernah lepas dengan seni khususnya terhadap musik apalagi dalam kehidupan sehari-hari. Gardner (1993) dengan teori multiple inteligences memperkuat pendapat bahwa seni khususnya music sangat berpengaruh dalam mengembangkan kecerdasan anak. Dari sekian perkembangan seni pada anak ini tentunya tidak hanya mempengaruhi bagian otaknya namun kegiatan seni dapat juga mempengaruhi motorik dan sosial terhadap anak. Sama halnya menurut Suyadi (2014) mengatakan bahwa seni merupakan salah satu stimulasi kreatif, artinya melibatkan seni dalam pembelajaran dapat mengaktifkan lebih banyak area-area dalam otak daripada tanpa melibatkan seni.

Berbagai macam kecerdasan yang sudah melekat pada diri anak kebanyakan dapat kita temui bakat tersebut dengan hal-hal kreatif yang dibuat oleh anak. Linderman \& Herberholz (1985) mengatakan bahwa prosesnya anak dituntut untuk lebih kreatif, menggunakan seni sebagai media pengembangan kreativitas, sehingga dapat dikatakan bahwa seni juga berfungsi untuk pengembangan bakat. Berdasarkan dari apa yang telah dimiliki oleh anak tentunya ia berkemampuan untuk bagaimana ia dapat membuat suatu karyanya sendiri, mengetahui lagu apa yang ia suka nyanyikan yang terkadang didengarkan melalui hp ataupun berbagai macam media lainnya serta memilih lagu yang mana paling digemari.

Pendapat yang sama diungkapkan oleh Gardner (1993) bahwa bakat seni merupakan cara berpikir seseorang tentang seni dan secara struktur bakat seni terdiri dari tiga bagian yaitu persepsi, produksi, dan refleksi. Persepsi dapat diartikan sebagai kemampuan melihat secara jelas perbedaan elemen atau kualitas sebuah objek; produksi yang dimaksud, yaitu kemampuan seseorang untuk menciptakan produk seni, sedangkan refleksi adalah kemampuan melihat diri sendiri dengan memahami karya orang lain dan mampu memilih objek sesuai dengan ketertarikan diri sendiri dan bukan karena orang lain.

Musik merupakan salah satu dari kegiatan seni yang dapat memberikan pembelajaran bagaimana menyusun nada atau suara sehingga menjadi perpaduan/kombinasi yang dapat menghasilkan suatu kesatuan dan memiliki kandungan/makna irama. Kegiatan bermusik atau bernyanyi pada anak usia dini merupakan kegiatan yang mengasikkan dan dapat mengembangkan aspek seni pada anak usia dini (Saputro, 2018). Hal ini sejalan dengan penelitian yang dilakukan oleh Dewi (2015) menyatakan bahwa musik merupakan alat dalam dunia pendidikan yang dapat memberikan dampak dan peranan penting terhadap emosi dan prestasi yang dimiliki anak.

Penelitian yang sama dilakukan oleh Satyadarma (2004) mengemukakan bahwa melalui kegiatan seni terutama musik, selain dapat mengembangkan aspek emosi anak juga dapat menambah wawasan anak terhadap hidup dan dapat memberikan anak tentang bagaimana mengekspresikan dirinya. Hal yang sama 
juga dikemukakan oleh Salahuddin (2019) bahwa musik dapat digunakan dalam berbagai hal yaitu sebagai sarana agar dapat meningkatkan spiritual, meskipun banyak perdebatan didalamnya musik juga banyak digunakan dalam dunia pendidikan.

Fungsi pembelajaran seni menurut Herawati (1999) yaitu sebagai media ekspresi, komunikasi, bermain, pengembangan bakat seni, kemampuan berpikir dan sebagai media untuk memperoleh pengalaman estetik. Dari fungsi pembelajaran seni yang sudah dikemukakan tersebut tentunya selalu bisa ditemukan dalam kehidupan keseharian anak-anak itu sendiri, ia akan mendapatkan bakat seninya berawal dari bagaimana anak belajar bernyanyi sambil bermain atau bermain sambil belajar. Dari bermain itulah yang dapat membantu anak agar dapat tetap belajar termasuk belajar tentang seni.

Melalui aspek seni dapat membantu anak dalam tumbuh dan kembangnya bahkan dapat membantu mengetahui bakat apa yang ada dalam diri anak dengan pendapat yang dikemukakan Sumanto (2005) mengatakan bahwa sebagai pengalaman edukatif seni dapat: (1) membantu pertumbuhan dan perkembangan anak, (2) seni dapat membina perkembangan estetik, (3) seni bermanfaat mengembangkan bakat, dan (4) seni membantu menyempurnakan kehidupan.

Pada diri setiap anak banyak hal yang sering mengekspresikan bagaimana perasaannya dengan melakukan berbagai kegiatan seperti bernyanyi, bergoyang bertepuk tangan, bahkan juga sering mengutarakan apa yang dirasakannya melalui menggambar. Menggambar merupakan hal yang dapat dilakukan anak untuk mengekspresikan apa yang diinginkan, atau yang dipikirkan secara kreatif. Beaty (2013) menyatakan bahwa "the key to setting up an environment that promotes creativity is freedom". Menurut Moeslichatoen (2004), salah satu cara yang banyak dilakukan anak untuk menyalurkan kreativitas anak adalah dengan menggambar. Dimana setiap anak memiliki kreativitas dengan caranya sendiri. Contohnya ketika melakukan kegiatan menggambar, anak melakukannya dengan sendiri dengan menggambar berbagai bentuk yang mereka buat sendiri.

Dari hasil penelitian yang dilakukan oleh Sophya (2019) mengenai model atau stimulasi untuk perkembangan seni pada anak usia dini yaitu memberikan pembelajaran yang sifatnya menyenangkan atau berupa permainan. Hal ini merupakan salah satu cara atau trik dalam menggiring anak untuk berkonsentrasi belajar sambil bermain. Adapun model pembelajaran seni yang dapat diajarkan untuk anak usia dini adalah dengan seni suara yaitu dengan bernyanyi.

Menurut Kurnia (2017) faktor yang mempengaruhi kreativitas anak usia dini yaitu: (1) memberikan stimulasi berupa rangsangan pada kepribadian atau suasana psikologis anak; (2) pola asuh orang tua; (3) guru yang memiliki sifat kreatif; dan (4) lingkungan yang kondusif serta mental yang dirangsang untuk mempengaruhi sistem kerja otak pada anak. Selain faktor tersebut, pendapat lain dari Huliyah (2016) bahwa perkembangan seni anak usia dini juga dapat didukung 
oleh penerapan pembelajaran seni yang menekan pada tiga aspek yaitu: (1) aspek eksplorasi; (2) aspek ekspresi; (3) aspek apresiasi.

\section{KESIMPULAN}

Hasil penelitian menyimpulkan bahwa keempat subjek telah memenuhi capaian perkembangan pada aspek Seni anak berdasarkan standar usia subjek khususnya dalam hal mampu membedakan antara bunyi dan suara (1. Mengenali berbagai macam suara dari Kendaraan, 2. Meminta untuk diperdengarkan lagu favorit secara berulang), Tertarik dengan kegiatan musik, gerakan orang, hewan maupun tumbuhan (1. Mendengarkan atau menyanyikan lagu, 2. Menggerakkan tubuh sesuai dengan irama, 3. Bertepuk tangan sesuai dengan irama music, 4. Meniru aktivitas orang baik secara langsung maupun melalui media, 5. Bertepuk tangan dengan pola yang berirama (misalnya bertepuk tangan sambil mengikuti irama nyanyian), dan tertarik dengan kegiatan atau karya seni (1. Menggambar dengan menggunakan beragam media (cat air, spidol, alat menggambar) dan cara (seperti finger painting, cat air, dII), 2. Membentuk sesuatu dengan plastisin, dan 3 . Mengamati dan membedakan benda disekitarnya yang diluar rumah).

Anak memenuhi capaian perkembangan karena berbagai upaya yang telah dilakukan oleh orang tua dalam pemberian stimulasi yakni: 1) Membiasakan diri anak untuk bisa belajar bunyi-bunyian, 2) Selalu memberikan perhatian khusus pada hal yang membuat anak tertarik, 3) memberikan dukungan positif terhadap apapun karya seni anak, 4) Memutarkan lagu-lagu saat anak sedang bermain, 5), Memberikan kebebasan kepada anak untuk bergerak mengikuti melodi lagu dan 6) Memberinya pujian atau hadiah ketika anak sudah mampu melakukan apa yang diajarkan, dan 7) Membiasakan diri anak lebih baik bermain dibanding harus selalu memegang handphone.

\section{DAFTAR PUSTAKA}

Astuti, F. (2011). Menggali dan Mengembangkan Potensi Kreativitas Seni pada Anak Usia Dini. Jurnal Bahasa Dan Seni, 14(2), 52-63.

Beaty, J. J. (2013). Observasi Perkembangan Anak Usia Dini. In Observasi Perkembangan Anak Usia Dini. Jakarta: Kencana.

Damayanti, E., Amaliah, A. R., \& Ismawati. (2020). Capaian dan Stimulasi Aspek Perkembangan Seni Pada Anak Kembar Usia 5 Tahun. Indonesian Journal of Early Childhood Education, 3(1), 1-17.

Dewi, M. P. (2015). Studi Metaanalisis: Musik Untuk Menurunkan Stres. Jurnal Psikologi, 36(2), 106 - 115-115. https://doi.org/10.22146/jpsi.7889

Farida, Purnani, W. T., \& Saidah, H. (2020). Pengaruh Pemberian Stimulasi Seni 
Melukis dengan Teknik Pointilis Terhadap Perkembangan Motorik Halus Pada Anak Prasekolah. Jurnal Mahasiswa Kesehatan, 1(2), 140-150.

Gardner, H. (1993). Multiple Intelligences. The Teory In Practice. New York: Basic Books.

Herawati. (1999). Pendidikan Seni Rupa. Jakarta: Depdiknas Dikti.

Huliyah, M. (2016). Pengembangan Daya Seni Pada Anak Usia Dini. Jurnal Penidikan Guru Rudhatul Athfal, 1(2), 1-14.

Khadijah. (2016). Pengembangan Kognitif Anak Usia Dini. Medan: Perdana Publishing.

Kurnia, S. D. (2017). Pengaruh Kegiatan Painting Dan Keterampilan Dalam Seni Lukis. Jurnal Tumbuh Kembang, 4(1), 66-75. https://doaj.org/article/9c30de88bcb8445893c969e6a55c3a72

Linderman, E. W., \& Herberholz, D. W. (1985). Developing Artistic and Perceptual Awareness: Art Practice in the Elementary Classroom. Dubuguwe, Lowa: W.C. Brown.

Marlina, L., \& Mayar, F. (2020). Pelaksanaan Kegiatan Finger Painting dalam Mengembangkan Kreativitas Seni Anak di Taman Kanak-Kanak. 4, 10181025.

Miskawati. (2017). Upaya Meningkatkan Kreatifitas Anak Dalam Pembelajaran Seni Tari Melalui Strategi Belajar Sambil Bermain di TK Islam Sa'adatul Khidmah Tahun Pelajaran 2016/2017. Jurnal IImiah Dikdaya, 9(1), 45-64.

Moeslichatoen. (2004). Metode Pengajaran di Taman Kanak-Kanak. Jakarta: Departemen Pendidikan Dan Kebudayaan.

Munandar, U. (2002). Kreativitas dan Keberbakatan (Strategi Mewujudkan Potensi dan Bakat). Jakarta: PT Gramedia Pustaka Utama.

Pakerti, W. (2010). Metode Pengembangan Seni. Jakarta: Universitas terbuka.

Rifda, E. F. (2017). Bimbingan dan Konseling Anak Usia Dini. Jakarta: PT Rajagrafindo Persada.

Riyanto, T., \& Martin, H. (2004). Pendidikan Pada Anak Usia Dini: Tuntunan Psikologis dan Pedagogis bagi Pendidikan dan Orangtua. Jakarta: PT Gramedia Widiasarana Indonedia.

Salahuddin, S. (2019). Mengadopsi Konser Musik Dalam Tradisi Tasawuf Ke Dunia Pendidikan Formal. NANAEKE: Indonesian Journal of Early Childhood Education, 2(1), 66. https://doi.org/10.24252/nananeke.v2i1.9384

Sandor, F. (1975). 9 Penerapan Gerak Dan Lagu. Lembang: P2PNFI Jayagiri. 
Saputro, F. A. (2018). Perkembangan Seni Anak Usia Dini (STPPA Tidak Tercapai) Studi Penelitian di RA Baiturrohmah, Tridadi, Sleman. Jurnal El-Hamra (Kependidikan Dan Kemasyarakatan) ISSN 2528-3650, 3(3), 55-61. http://ejournal.el-hamra.id/index.php/el/article/view/54

Sari, A. . (2020). STUDI KASUS STRATEGI GURU DALAM KEGIATAN MENGGAMBAR UNTUK. Jurnal Pendidikan Anak Usia Dini, 4(2), 150-155.

Satyadarma, M. (2004). Cerdas dengan Musik. Jakarta: Niaga Swadaya.

Sophya, I. V. (2019). Model Pembelajaran Kesenian di PAUD Ya Ummi Fat Desa Bermi Kecamatan Mijen Kabupaten Demak (Studi Analisis Kurikulum Kesenian untuk Prodi PGRA STAIN Kudus). ThufuLA: Jurnal Inovasi Pendidikan Guru Raudhatul Athfal, 3(1), 79. https://doi.org/10.21043/thufula.v3i1.4654

Sujiono, N. (2009). Konsep Dasar Pendidikan Anak Usia Dini. Jakarta: Indeks.

Sumanto. (2005). Pengembangan Kreativitas Seni Rupa Anak TK. Jakarta: Depdiknas.

Supriyenti, A. (2013). Meningkatkan Kreativitas Seni Rupa Anak Melalui Kegiatan Mencetak Dengan Bahan Alam di PAUD Aisyiyah Lansano Pesisir Selatan. Spektrum PLS, 1(2), 15-34.

Suyadi. (2014). Teori Pembelajaran Anak Usia Dini. Bandung: PT. Remaja Rosdakarya.

Tiurma, M. (2012). Pendidikan Seni Melalui Kegiatan Bernyanyi pada Anak Usia Dini. Surabaya: Universitas Negeri Surabaya.

Widiasaran. (1999). Pengembangan Kreativitas Anak Berbakat. Jakarta: PT Rineka Cipta.

Wulandari, A., Bahrun, \& Rosmiati. (2020). Meningkatkan Kreativitas Anak Melalui Teknuik Finger Paintig di KB Al Jannati Gampong Jawa Kota Banda Aceh. Jurnal IImiah Mahasiswa Pendidikan Guru Anak Usia Dini, 5(1), 80-89. 